\title{
Nano-Materials and Composition on the Basis of Cobalt Nano-Particles and Fine Humic Acids as Stimulators of New Generation Growth
}

\author{
Polishchuk Svetlana Dmitrievna ${ }^{1}$, Nazarova Anna Anatolievna ${ }^{1}$, Kutskir Maxim Valerievich ${ }^{1}$ and Churilov \\ Gennady Ivanovich ${ }^{2}$ \\ 1. Technological Faculty, Chemistry Department, Ryazan State Agrotechnological University by P.A. Kostychev, Russia \\ 2. Faculty of Pharmacy, Department of General Chemistry with Courses of Organic and Bioorganic Chemistry, Ryazan State \\ Medical University, Russia
}

Received: January 16, 2014 / Accepted: February 06, 2014 / Published: February 25, 2014.

\begin{abstract}
The aim of the investigations is to study growth stimulators increasing crop yield and quality, for example the sunflower. Nano-cobalt, humic acids in nano-dispersed state and their combination have been chosen as stimulators. The work has taken place both in the lab and in the field. Field emergence, leaf-area duration, the plants' height and mass in different phases of vegetation, the yield and chemical composition of the sunflower seeds have been determined when meteorology of 2013. The seeds have been treated with stimulators having the concentration from 0.01 to $10.0 \mathrm{~g}$ per hectare, and in the field conditions with that of $0.5 \mathrm{~g} / \mathrm{ha}, 1.0 \mathrm{~g} / \mathrm{ha}, 5.0$ $\mathrm{g} / \mathrm{ha}$. In a case with nano-cobalt the field emergence has increased per $11.6 \%$,in a case with humic acids, $11.2 \%$ higher than that of the control. The case with these substances complex has increased the datum per 17.8\%. Cobalt nano-particles have increased the green material per $19 \%$, the humic acids, per $22 \%$ and their combination, per $30 \%$. The yield increase in a case with different stimulators has been $24 \%, 19 \%, 31 \%$ correspondingly. The protein increase in a case with the combination of humic acids and cobalt nano-particles has comprised $7.24 \%$. This research is important for understanding the mechanism of action nanostructures in biologycal objects.
\end{abstract}

Key words: Sunflower, biochemistry, plant physiology, metallic nanopowder, plant development.

\section{Introduction}

The application of nanotechnology in agriculture is becoming more urgent year by year as in future it will solve the problem of food security in the Russian Federation and in the world. Biogenic metals nano-particles possess biological activity and can be used as crop growth stimulators, increasing productivity and quality of agricultural products. Studies of biological properties of metal nano-particles to introduce them in crop growing as a new generation of biological products have taken place at Ryazan State

Coresponding authors: Churilov Gennady Ivanovich, doctor, professor, research fields: nanoparticles, plant biochemistry, plant physiology. E-mail: genchurilov@yandex.ru.
Agrotechnological University for 20 years. According to the results of repeated experiments they have proved and confirmed by field trials that nano-particles promote crop yield increase and accumulation of biologically active polymers and can be used in cattle breeding. Humic acids are effective stimulators of plants growth and development. These are organic substances which are an integral part of the soil, derived from natural products (peat, lignite, bituminous coal) by alkali water. Sets of positively and negatively charged groups within molecules of humic acids give them multi-functionality [1-10].

Small size (20-35 nm), particles shape and structure peculiarities attribute them unique enzymatic properties and active biological potential that one can 
implement in crop growing.

The aim of the research is determining the optimal concentration of cobalt nano-particles and humic acids in nano-dispersive state as well as their complex in a case of treating sunflower seeds. We have also studied these small structures optimal concentration influence on sunflower growth, development and yield.

Preliminary laboratory tests with spring wheat, spring barley, corn and canola have showed that cobalt nano-particles and humic acids are fine. This fact makes it possible to continue research on sunflower.

\section{Materials and Methods}

Laboratory studies were conducted at the Department of Chemistry FSBEI HPE RSATU. We used sunflower hybrid seeds of the first generation "Donskoy 22". We determined the germination energy and laboratory coming-up according to GOST 12038-84 "Crop seeds. Methods of determining coming-up and germination energy" and according to the procedure "Determining the impact of nano-materials on food and fodder plants concerning vital and morpho-physiologic indicators" [11] developed and tested under a grant of the federal target program of the Russian Federation "Nano-industry infrastructure development in the Russian Federation for 2008-2011". We have determined the germination energy on the third day of sunflower seeds germination and their lab coming-up, plantlets and roots length and mass on the seventh day.

Field studies were carried out in 2011-2013 at an agro-technical farm of FSBEI HPE RSATU in
Stenkino township of Ryazan district, Ryazan oblast. The experiment took place according to Dospehov's method of field experiments [12]. Plots location is systematic with fourfold replication. The acreage of plots is $100 \mathrm{~m}^{2}$ and that of a harvesting area is $80 \mathrm{~m}^{2}$ with fourfold replication. The experiment was unifactor. The factor was sunflower seeds pre-plant treatment with different biologically active nano-substances: cobalt nano-particles, highly-dispersive humic acids and the complex of these substances. In the course of vegetation we determined the following parameters: field germination, leaf-area duration, plant height and weight in phases of vegetation, sunflower seeds yield and chemical composition.

Meteorology in 2013. On the background of increased air temperature in May 2013 (the average annual air temperature data exceeded the average annual data by $8.5 \mathrm{C}^{0}$ ) we have had rain within normal limits. Moisture deposits were sufficient for seeds imbibition and early germination. The seedlings appeared on the eighth day after sowing. We had only $49 \%$ of normal rainfall in June that affected the plants linear growth. They had a small height as compared with the average data. In the third decade of June we had rain $40.3 \mathrm{~mm}$ below the norm.

\section{Findings and Determination}

We determined the sunflower seeds vital figures under the influence of different concentration of nano-dimensioned biologically active substances at the first stage of lab experiments (Table 2).

Table 1 The chart of lab and field experiments.

\begin{tabular}{lll}
\hline$\#$ & Variants & Concentration of the studied nano-substances, g per ha norm of seeds planting \\
\hline & & \multicolumn{1}{c}{ Lab experiments } \\
\hline 1. & Control & - \\
2. & Cobalt nano-particles (NP-Co) & $0.01 ; 0.05 ; 0.1 ; 0.5 ; 1.0 ; 2.5 ; 5.0 ; 10.0$ \\
3. & Humic acids (HA) in ultra-disperse state & $0.01 ; 0.05 ; 0.1 ; 0.5 ; 1.0 ; 2.5 ; 5.0 ; 10.0$ \\
4. & HA+ NP-Co & $0.01 ; 0.05 ; 0.1 ; 0.5 ; 1.0 ; 2.5 ; 5.0 ; 10.0$ \\
\hline & & \multicolumn{1}{c}{ Field experiments } \\
\hline 1. & Control & - \\
2. & Cobalt nano-particles (NP-Co) & $0.5 ; 1.0 ; 5.0$ \\
3. & Humic acids (HA) in ultra-disperse state & $0.5 ; 1.0 ; 5.0$ \\
4. & HA+ NP-Co & $0.5 ; 1.0 ; 5.0$ \\
\hline
\end{tabular}



Stimulators of New Generation Growth

Table 2 Vital indexes of sunflower seeds when treated with biologically active nano-particles.

\begin{tabular}{|c|c|c|c|c|c|}
\hline Variant & Figures & Variant & Figures & Variant & Figures \\
\hline \multicolumn{6}{|c|}{ Germination energy (\%) } \\
\hline Control & 89.0 & Control & 89.0 & Control & 89.0 \\
\hline NP-Co 0.01 & 92.3 & $\mathrm{HA}-0.01$ & 91.3 & $\mathrm{NP}-\mathrm{Co}+\mathrm{HA} 0.01$ & 92.3 \\
\hline NP-Co 0.05 & 92.4 & $\mathrm{HA}-0.05$ & 91.4 & $\mathrm{NP}-\mathrm{Co}+\mathrm{HA} 0.05$ & 92.0 \\
\hline NP-Co 0.1 & 92.8 & $\mathrm{HA}-0.1$ & 92.5 & NP-Co + HA 0.1 & 93.1 \\
\hline NP-Co 0.5 & 96.0 & HA- 0.5 & 94.6 & $\mathrm{NP}-\mathrm{Co}+\mathrm{HA} 0.5$ & 98.5 \\
\hline NP-Co 1.0 & 94.4 & $\mathrm{HA}-1.0$ & 93.4 & $\mathrm{NP}-\mathrm{Co}+\mathrm{HA} 1.0$ & 94.8 \\
\hline NP-Co 2.5 & 93.2 & $\mathrm{HA}-2.5$ & 92.4 & $\mathrm{NP}-\mathrm{Co}+\mathrm{HA} 2.5$ & 94.6 \\
\hline NP-Co 5.0 & 94.3 & $\mathrm{HA}-5.0$ & 94.7 & NP-Co + HA 5.0 & 94.2 \\
\hline NP-Co 10.0 & 89.4 & $\mathrm{HA}-10.0$ & 92.3 & NP-Co + HA 10.0 & 94.1 \\
\hline \multicolumn{6}{|c|}{ Lab coming-up (\%) } \\
\hline Control & 94.0 & Control & 94.0 & Control & 94.0 \\
\hline NP-Co 0.01 & 96.6 & $\mathrm{HA}-0.01$ & 94.5 & NP-Co + HA 0.01 & 95.4 \\
\hline NP-Co 0.05 & 96.8 & $\mathrm{HA}-0.05$ & 93.6 & $\mathrm{NP}-\mathrm{Co}+\mathrm{HA} 0.05$ & 95.2 \\
\hline NP-Co 0.1 & 94.6 & $\mathrm{HA}-0.1$ & 96.3 & $\mathrm{NP}-\mathrm{Co}+\mathrm{HA} 0.1$ & 96.5 \\
\hline NP-Co 0.5 & 99.0 & HA- 0.5 & 97.6 & $\mathrm{NP}-\mathrm{Co}+\mathrm{HA} 0.5$ & 100.0 \\
\hline NP-Co 1.0 & 98.5 & $\mathrm{HA}-1.0$ & 98.2 & NP-Co + HA 1.0 & 98.6 \\
\hline NP-Co 2.5 & 96.5 & $\mathrm{HA}-2.5$ & 97.4 & $\mathrm{NP}-\mathrm{Co}+\mathrm{HA} 2.5$ & 99.8 \\
\hline NP-Co 5.0 & 95.4 & $\mathrm{HA}-5.0$ & 94.7 & NP-Co + HA 5.0 & 97.1 \\
\hline NP-Co 10.0 & 95.2 & $\mathrm{HA}-10.0$ & 94.5 & $\mathrm{NP}-\mathrm{Co}+\mathrm{HA} 10.0$ & 96.0 \\
\hline
\end{tabular}

Analysis of the data from Table 2 has shown that the use of cobalt nano-particles enhances germination of sunflower seeds. So the germination energy in all experiment variants has been on average $4 \%$ higher than that of control variants. The maximum energy value in a case of using cobalt nano-particles happened with concentration of $0.5 \mathrm{~g}$ per hectare seeding rate. The quantity of germinating seeds on the $3 \mathrm{~d}$ day exceeded the control per $7 \%$. It is noteworthy that further increase of concentration up to $10.0 \mathrm{~g}$ has promoted the germination energy reduction. Lab germinating has also exceeded the control one in all experiment variants with cobalt nano-particles having concentration of $0.5 \mathrm{~g}$. The germination rate is practically $99 \%$.

Nano-dispersed humic acids usage has promoted germinating stimulation both on the $3 \mathrm{~d}$ day of the experiment and on the 7th one. One can see the highest effect with humid acids concentration from 0.01-1.0 $\mathrm{g} / \mathrm{ha}$. The germination energy has exceeded the control one per $5.7 \%-2.3 \%$. Lab germinating with all concentration has also been higher than that of the control.

One can see the best result while seeds germinating when they used cobalt nano-particles together with humic acids. When concentration of the complex is 0.5 $\mathrm{g}$ the sunflower seeds germinating energy has been maximum among all experiment variants and exceeded the control ones per $9.5 \%$. Lab germinating with this concentration has been $100 \%$.

On the 2nd stage of laboratory tests we have studied the influence of nano-dimensioned substances with various concentrations on morpho-physiologic figures of sunflower plantlets (Table 3 and 4).

Thus the usage of cobalt nano-particles and fine humic acids together with the complex of used substances promotes the increase of both aerial and underground portions of sunflower plantlets. So the use of cobalt nano-particles has increased the length of plantlets' aerial portion as compared with that of the control group per $15.5 \%$ in a case of cobalt nano-particles concentration equal to $0.5 \mathrm{~g}$. When increasing the concentration from 2.5 to $10 \mathrm{~g}$ the deviation from the control group is insignificant, that is 
Table 3 Morphologic figures of sunflower seeds when treated with biologically active nano-particles.

\begin{tabular}{|c|c|c|c|c|c|}
\hline Variant & $\begin{array}{l}\text { Plantlets aerial portion } \\
\text { length }(\mathrm{mm})\end{array}$ & Variant & $\begin{array}{l}\text { Plantlets aerial portion } \\
\text { length }(\mathrm{mm})\end{array}$ & Variant & $\begin{array}{l}\text { Plantlets aerial portion } \\
\text { length }(\mathrm{mm})\end{array}$ \\
\hline Control & 15.6 & Control & 15.6 & Control & 15.6 \\
\hline NP-Co 0.01 & 16.7 & HA-0.01 & 15.9 & NP-Co + HA 0.01 & 16.2 \\
\hline NP-Co 0.05 & 16.4 & HA- 0.05 & 16.4 & $\mathrm{NP}-\mathrm{Co}+\mathrm{HA} 0.05$ & 16.5 \\
\hline NP-Co 0.1 & 18.4 & HA-0.1 & 15.3 & NP-Co + HA 0.1 & 17.3 \\
\hline NP-Co 0.5 & 19.4 & HA- 0.5 & 16.7 & NP-Co + HA 0.5 & 18.4 \\
\hline NP-Co 1.0 & 18.7 & HA-1.0 & 17.5 & NP-Co + HA 1.0 & 15.6 \\
\hline NP-Co 2.5 & 16.4 & HA-2.5 & 16.8 & NP-Co + HA 2.5 & 15.6 \\
\hline NP-Co 5.0 & 16.7 & HA-5.0 & 16.5 & NP-Co + HA 5.0 & 16.7 \\
\hline NP-Co 10.0 & 15.9 & HA-10.0 & 16.5 & $\mathrm{NP}-\mathrm{Co}+\mathrm{HA} 10.0$ & 16.6 \\
\hline Variant & $\begin{array}{l}\text { Plantlets subterranean } \\
\text { portion length }(\mathrm{mm})\end{array}$ & Variant & $\begin{array}{l}\text { Plantlets subterranean } \\
\text { portion length }(\mathrm{mm})\end{array}$ & Variant & $\begin{array}{l}\text { Plantlets portion } \\
\text { subterranean length }(\mathrm{mm})\end{array}$ \\
\hline Control & 13.8 & Control & 13.8 & Control & 13.8 \\
\hline NP-Co 0.01 & 14.0 & HA-0.01 & 13.4 & $\mathrm{NP}-\mathrm{Co}+\mathrm{HA} 0.01$ & 14.4 \\
\hline NP-Co 0.05 & 13.8 & HA- 0.05 & 14.6 & $\mathrm{NP}-\mathrm{Co}+\mathrm{HA} 0.05$ & 15.3 \\
\hline NP-Co 0.1 & 15.3 & HA-0.1 & 14.8 & NP-Co + HA 0.1 & 15.3 \\
\hline NP-Co 0.5 & 16.4 & HA- 0.5 & 15.3 & NP-Co + HA 0.5 & 16.6 \\
\hline NP-Co 1.0 & 15.6 & HA-1.0 & 16.3 & NP-Co + HA 1.0 & 16.4 \\
\hline NP-Co 2.5 & 15.2 & HA-2.5 & 14.3 & NP-Co + HA 2.5 & 17.4 \\
\hline NP-Co 5.0 & 15.5 & HA-5.0 & 14.2 & $\mathrm{NP}-\mathrm{Co}+\mathrm{HA} 5.0$ & 14.4 \\
\hline NP-Co 10.0 & 14.4 & HA-10.0 & 14.6 & $\mathrm{NP}-\mathrm{Co}+\mathrm{HA} 10.0$ & 15.6 \\
\hline
\end{tabular}

Table 4 Mass figures of sunflower seeds when treated with biologically active nano-particles.

\begin{tabular}{|c|c|c|c|c|c|}
\hline Variant & $\begin{array}{l}\text { Plantlets aerial portion } \\
\text { mass }(\mathrm{g})\end{array}$ & Variant & $\begin{array}{l}\text { Plantlets aerial portion } \\
\text { mass }(\mathrm{g})\end{array}$ & Variant & $\begin{array}{l}\text { Plantlets aerial portion mass } \\
\text { (g) }\end{array}$ \\
\hline Control & 19.07 & Control & 19.07 & Control & 19.07 \\
\hline NP-Co 0.01 & 20.20 & $\mathrm{HA}-0.01$ & 20.20 & $\mathrm{NP}-\mathrm{Co}+\mathrm{HA} 0.01$ & 22.40 \\
\hline NP-Co 0.05 & 21.90 & $\mathrm{HA}-0.05$ & 20.80 & $\mathrm{NP}-\mathrm{Co}+\mathrm{HA} 0.05$ & 24.30 \\
\hline NP-Co 0.1 & 20.90 & $\mathrm{HA}-0.1$ & 21.50 & $\mathrm{NP}-\mathrm{Co}+\mathrm{HA} 0.1$ & 23.80 \\
\hline NP-Co 0.5 & 25.70 & $\mathrm{HA}-0.5$ & 22.50 & NP-Co + HA 0.5 & 26.50 \\
\hline NP-Co 1.0 & 23.40 & $\mathrm{HA}-1.0$ & 24.70 & NP-Co + HA 1.0 & 25.40 \\
\hline NP-Co 2.5 & 21.60 & $\mathrm{HA}-2.5$ & 23.50 & $\mathrm{NP}-\mathrm{Co}+\mathrm{HA} 2.5$ & 24.60 \\
\hline NP-Co 5.0 & 22.50 & $\mathrm{HA}-5.0$ & 24.80 & NP-Co + HA 5.0 & 23.70 \\
\hline NP-Co 10.0 & 21.50 & $\mathrm{HA}-10.0$ & 24.40 & $\mathrm{NP}-\mathrm{Co}+\mathrm{HA} 10.0$ & 22.30 \\
\hline Variant & $\begin{array}{l}\text { Plantlets subterranean } \\
\text { portion mass }(\mathrm{g})\end{array}$ & Variant & $\begin{array}{l}\text { Plantlets subterranean } \\
\text { portion mass }(\mathrm{g})\end{array}$ & Variant & $\begin{array}{l}\text { Plantlets subterranean } \\
\text { portion mass }(\mathrm{g})\end{array}$ \\
\hline Control & 3.12 & Control & 3.12 & Control & 3.12 \\
\hline NP-Co 0.01 & 3.42 & $\mathrm{HA}-0.01$ & 4.32 & $\mathrm{NP}-\mathrm{Co}+\mathrm{HA} 0.01$ & 4.63 \\
\hline NP-Co 0.05 & 4.54 & $\mathrm{HA}-0.05$ & 4.52 & $\mathrm{NP}-\mathrm{Co}+\mathrm{HA} 0.05$ & 5.32 \\
\hline NP-Co 0.1 & 4.52 & $\mathrm{HA}-0.1$ & 5.62 & NP-Co + HA 0.1 & 5.62 \\
\hline NP-Co 0.5 & 5.74 & $\mathrm{HA}-0.5$ & 4.85 & $\mathrm{NP}-\mathrm{Co}+\mathrm{HA} 0.5$ & 5.81 \\
\hline NP-Co 1.0 & 5.63 & $\mathrm{HA}-1.0$ & 3.98 & $\mathrm{NP}-\mathrm{Co}+\mathrm{HA} 1.0$ & 5.46 \\
\hline NP-Co 2.5 & 4.72 & $\mathrm{HA}-2.5$ & 4.62 & $\mathrm{NP}-\mathrm{Co}+\mathrm{HA} 2.5$ & 5.71 \\
\hline NP-Co 5.0 & 4.71 & $\mathrm{HA}-5.0$ & 4.71 & $\mathrm{NP}-\mathrm{Co}+\mathrm{HA} 5.0$ & 4.87 \\
\hline NP-Co 10.0 & 4.21 & $\mathrm{HA}-10.0$ & 3.89 & $\mathrm{NP}-\mathrm{Co}+\mathrm{HA} 10.0$ & 4.61 \\
\hline
\end{tabular}

why the optimum concentration of cobalt nano-particles is $0.5 \mathrm{~g}$.

The maximum length of plantlets in a case of humic acids concentration equal to $1.0 \mathrm{~g}$ is $17.5 \mathrm{~mm}$. That is $12 \%$ higher than that in the control group. The most significant plantlet length difference with the control 
group is in the variant of the complex of humid acids and cobalt nano-particles. The length of the plantlet aerial portion in all the variants goes beyond the control group. The length of the aerial portion has gone beyond the control group per $18 \%$ while the length of the underground portion has been $20 \%$ more than the control group in a case with 0.5 gr concentration of the active substance.

The data from Table 4 witness that the mass of the aerial and underground portions of plantlets in all variants exceeds the control considerably and the plantlets growth and development processes go more intensive when they treated the seeds with biologically active nano-particles. The plantlets mass in a case of cobalt nano-particles treatment has been maximal with $0.5 \mathrm{~g}$ concentration. The mass of the aerial portion has exceeded the control per $34 \%$, the underground portion mass per $83 \%$. In a case of using highly-dispersed humic acids the average aerial portion mass excess over control has been $18 \%$ and that of the underground portion, $52 \%$. The complex of cobalt nano-particles and humid acids has shown large biological activity in consequence of which the plantlets mass in a given variant has been maximal. The excess of the aerial portion mass composes $25.5 \%$ and that of the underground one $74 \%$.

The conducted lab investigations have proved high biological activity of cobalt nano-particles, highly-dispersed humic acids and these substances complex. On the basis of the data we got for the next stage of our investigation in the field we have chosen the optimal concentrations of biological products, videlicet $0.5 \mathrm{~g}, 1.0 \mathrm{~g}$ and $5.0 \mathrm{~g}$ per hectare seeding rate.

The temperature in the sunflower vegetation period in phases has been a little higher than the average one in the region (Table 6). This gives explanation for the shorter period of experimental plants vegetation. On the whole the plants have got the optimum temperature inventory for optimal physiologic processes due to good rainfall and high daily mean temperature. As a result this has lead to forming good oil yield.

The use of cobalt nano-particles, humic acids and the combination of these substances has promoted authentic increase of field germination (Table 7). So using cobalt nano-particles increases field germination per $11.6 \%(0.5 \mathrm{~g})$. The field germination for humic

Table 5 Sunflower vegetation period and its duration (2013 data).

\begin{tabular}{|c|c|c|c|c|c|c|}
\hline $\begin{array}{l}\text { Date of } \\
\text { seeding }\end{array}$ & $\begin{array}{l}\text { Seeds } \\
\text { germination } \\
\text { May 20, } 2013 \text { to } \\
\text { June 3, 2013 }\end{array}$ & $\begin{array}{l}\text { Seeding } \\
\text { emergence } \\
\text { June } 3,2013 \text { to } \\
\text { July 9, } 2013\end{array}$ & $\begin{array}{l}\text { Budding-flowering } \\
\text { July } 9,2013 \text { to August } \\
6,2013\end{array}$ & $\begin{array}{l}\text { Flowering-maturing } \\
\text { August 6, } 2013 \text { to } \\
\text { September 9, } 2013\end{array}$ & $\begin{array}{l}\text { Complete ripeness } \\
\text { September 9, } 2013 \\
\text { to September 13, } \\
2013\end{array}$ & $\begin{array}{l}\text { Seeding - complete } \\
\text { ripeness } \\
\text { May 20, } 2013 \text { to } \\
\text { September } 13,2013\end{array}$ \\
\hline $\begin{array}{l}\text { May 20, } \\
2013\end{array}$ & 13 days & 36 days & 28 days & 36 days & 4 days & 117 days \\
\hline
\end{tabular}

Table 6 Effective temperature sum (2013 data).

\begin{tabular}{|c|c|c|c|c|c|c|}
\hline $\begin{array}{l}\text { Date of } \\
\text { seeding }\end{array}$ & $\begin{array}{l}\text { Seeds } \\
\text { germination } \\
\text { May 20, } 2013 \text { to } \\
\text { June 3, } 2013\end{array}$ & $\begin{array}{l}\text { Seeding } \\
\text { emergence } \\
\text { June } 3,2013 \text { to } \\
\text { July } 9,2013\end{array}$ & $\begin{array}{l}\text { Budding-flowering } \\
\text { July } 9,2013 \text { to August } \\
6,2013\end{array}$ & $\begin{array}{l}\text { Flowering-maturing } \\
\text { August 6, } 2013 \text { to } \\
\text { September 9, } 2013\end{array}$ & $\begin{array}{l}\text { Complete ripeness } \\
\text { September } 9,2013 \\
\text { to September } 13 \text {, } \\
2013\end{array}$ & $\begin{array}{l}\text { Seeding-complete } \\
\text { ripeness } \\
\text { May 20, } \\
2013-\text { September 13, } \\
2013\end{array}$ \\
\hline $\begin{array}{l}20.05 .20 \\
13\end{array}$ & $282.4 \mathrm{C}^{0}$ & $742 \mathrm{C}^{0}$ & $549.5 \mathrm{C}^{0}$ & $675.3 \mathrm{C}^{0}$ & $119.3 \mathrm{C}^{0}$ & $2368.5 \mathrm{C}^{0}$ \\
\hline
\end{tabular}

Table 7 Field emergence of sunflower.

\begin{tabular}{llllll}
\hline Variant & \multicolumn{1}{l}{ Field emergence (\%) } & Variant & Field emergence (\%) & Variant & Field emergence (\%) \\
\hline Control & 80.4 & Control & 80.4 & Control & 80.4 \\
NP-Co -0.5 & 92.0 & HA -0.5 & 90.3 & NP-Co + HA - 0.5 & 98.2 \\
NP-Co -1.0 & 91.4 & HA -1.0 & 91.6 & NP-Co + HA - 1.0 & 96.4 \\
NP-Co -5.0 & 88.0 & HA -5.0 & 89.6 & NP-Co + HA - 5.0 & 93.7 \\
\hline
\end{tabular}


acids has surpassed the control at most per $11.2 \%$ with the concentration of $1.0 \mathrm{~g}$. We achieved the best result in a case of simultaneous use of the studied biologically active substances. Within the interval of all concentrations the field germination has surpassed the control at most with $0.5 \mathrm{~g}$ concentration per $17.8 \%$.

From the data of the Table 8 one can see that the height of experimental sunflower plants in the phase when the $3 \mathrm{~d}$ pair of leaves appear has surpassed the control in all variants. The largest difference with the control can be found in the variant with the combination of cobalt nano-particles and highly-dispersed humic acids (up to 25\%). When we used cobalt nano-particles the plant height has been higher that that of the control one per $17.8 \%$ on the average. The humic acids have shown the best result with the concentration of $5.0 \mathrm{~g}$. the plants height has been more tham that of the control ones per $15 \%$. The experimental plants mass has also been higher than the control one in all the variants. The use of cobalt nano-particles has allowed increasing the green material on the average per $19 \%$. The humic acids have stimulated the green material accumulation on the average per $22 \%$ and the complex of biologically active substances per $30 \%$ as compared with the control.

Table 9 presents the data connected with the mass and height of sunflower plants in the phase of blossoming.

The provided data prove that the use of cobalt nano-particles, highly-dispersed humic acids and their combination stimulates the sunflowers growth and development during the whole period of vegetation from the phase when the plantlet appears till ripening. The plants height in a case of cobalt nano-particles pre-plant treatment has exceeded that of the control per $7.1 \%$ with the concentration of $0.5 \mathrm{~g}$. Humic acids have

Table 8 Height and mass of sunflower plants in the phase of the 3d pair of leaves.

\begin{tabular}{|c|c|c|c|c|c|}
\hline \multicolumn{6}{|c|}{ Plants height } \\
\hline Variant & Plants height $(\mathrm{cm})$ & Variant & Plants height $(\mathrm{cm})$ & Variant & Plants height $(\mathrm{cm})$ \\
\hline Control & 34.6 & Control & 34.6 & Control & 34.6 \\
\hline NP-Co -0.5 & 41.3 & $\mathrm{HA}-0.5$ & 35.2 & $\mathrm{NP}-\mathrm{Co}+\mathrm{HA}-0.5$ & 43.5 \\
\hline NP-Co -1.0 & 40.3 & $\mathrm{HA}-1.0$ & 36.4 & $\mathrm{NP}-\mathrm{Co}+\mathrm{HA}-1.0$ & 40.2 \\
\hline NP-Co -5.0 & 38.5 & $\mathrm{HA}-5.0$ & 39.8 & $\mathrm{NP}-\mathrm{Co}+\mathrm{HA}-5.0$ & 37.6 \\
\hline \multicolumn{6}{|c|}{ Plants mass } \\
\hline Variant & A plant mass (g) & Variant & A plant mass $(\mathrm{g})$ & Variant & A plant mass (g) \\
\hline Control & 245 & Control & 245 & Control & 245 \\
\hline NP-Co -0.5 & 320 & $\mathrm{HA}-0.5$ & 275 & $\mathrm{NP}-\mathrm{Co}+\mathrm{HA}-0.5$ & 354 \\
\hline NP-Co -1.0 & 290 & $\mathrm{HA}-1.0$ & 313 & $\mathrm{NP}-\mathrm{Co}+\mathrm{HA}-1.0$ & 335 \\
\hline NP-Co -5.0 & 264 & $\mathrm{HA}-5.0$ & 323 & $\mathrm{NP}-\mathrm{Co}+\mathrm{HA}-5.0$ & 314 \\
\hline
\end{tabular}

Table 9 Height and mass of sunflower plants when blossoming.

\begin{tabular}{|c|c|c|c|c|c|}
\hline \multicolumn{6}{|c|}{ Plants height } \\
\hline Variant & Plants height $(\mathrm{cm})$ & Variant & Plants height $(\mathrm{cm})$ & Variant & Plants height $(\mathrm{cm})$ \\
\hline Control & 95.9 & Control & 95.9 & Control & 95.9 \\
\hline $\mathrm{NP}-\mathrm{Co}-0.5$ & 102.8 & $\mathrm{HA}-0.5$ & 96.5 & $\mathrm{NP}-\mathrm{Co}+\mathrm{HA}-0.5$ & 106.3 \\
\hline NP-Co - 1.0 & 99.9 & $\mathrm{HA}-1.0$ & 99.6 & $\mathrm{NP}-\mathrm{Co}+\mathrm{HA}-1.0$ & 98.9 \\
\hline NP-Co -5.0 & 98.3 & $\mathrm{HA}-5.0$ & 105.9 & NP-Co + HA - 5.0 & 104.5 \\
\hline \multicolumn{6}{|c|}{ Plants mass } \\
\hline Variant & A plant mass (g) & Variant & A plant mass (g) & Variant & A plant mass (g) \\
\hline Control & 690 & Control & 690 & Control & 690 \\
\hline NP-Co -0.5 & 980 & $\mathrm{HA}-0.5$ & 710 & $\mathrm{NP}-\mathrm{Co}+\mathrm{HA}-0.5$ & 1,020 \\
\hline NP-Co - 1.0 & 790 & $\mathrm{HA}-1.0$ & 740 & $\mathrm{NP}-\mathrm{Co}+\mathrm{HA}-1.0$ & 810 \\
\hline NP-Co -5.0 & 740 & $\mathrm{HA}-5.0$ & 940 & $\mathrm{NP}-\mathrm{Co}+\mathrm{HA}-5.0$ & 720 \\
\hline
\end{tabular}


also stimulated the process of sunflowers growth and development. The plants height in all variants has surpassed the control up to $10.3 \%$. We have got the best result when used the combination of cobalt nano-particles and humid acids in ultra-fine state. The plants height has been the largest among the experiment variants and surpassed that of the control per $11 \%$.

The mass of the plants from the experiment plots has also been bigger than that of the control group in all variants. So the mass of the plants when we used cobalt nano-particles has been maximal with the concentration equal to $0.5 \mathrm{~g}$ and exceeded the control per $42 \%$ while in ther case with humic acids per $19 \%$. The use of cobalt nano-particles and humic acids combination with the concentration equal to $0.5 \mathrm{~g}$ has promoted the plants mass increase per $47.8 \%$ in comparison with the control one. This testifies that the used biologically active preparations stimulate physiologic and bio-chemical processes and promote the formation of well-balanced yield according to quantitative and qualitative characteristics (Tables 10 and 11).
Table 10 presents the data concerning the sunflower yield under the influence of biologically active nano-materials. The use of cobalt nano-particles with concentration of $0.5 \mathrm{~g}$ has led to $24 \%$ yield increase as compare with that of the control. In a case with highly-dispersed humic acids the maximal yield has been achieved with $5.0 \mathrm{~g}$ concentration that is $19 \%$ higher than in the control group. The combination of cobalt nano-particles and ultra-dispersed humic acids has promoted the sunflower's maximal yield increase (31\%) with concentration of $0.5 \mathrm{~g}$.

The chemical analysis of the sunflower seeds from both experimental and controlled groups is represented in Table 11.

The chemical composition of sunflower seeds reflects the character of biologically active nano-particles influence on bio-chemical metabolic processes and processes of biologically active substances accumulation. Ash amount characterizes mineral metabolism in plants. Table 11 presents the data proving that the use of cobalt nano-particles and ultra-dispersed humic acids as well as their combination promotes seeds ash content increase of all experiment

Table 10 Sunflower yield.

\begin{tabular}{llllll}
\hline Variant & Yield (c/ha) & Variant & Yield (c/ha) & Variant & Yield (c/ha) \\
\hline Control & 20.4 & Control & 20.4 & Control & 20.4 \\
NP-Co -0.5 & 25.3 & HA -0.5 & 21.2 & NP-Co + HA -0.5 & 26.7 \\
NP-Co -1.0 & 23.6 & HA -1.0 & 22.7 & NP-Co + HA -1.0 & 22.4 \\
NP-Co -5.0 & 21.5 & HA -5.0 & 24.3 & NP-Co + HA -5.0 & 23.3 \\
\hline
\end{tabular}

Table 11 Chemical composition of sunflower seeds.

\begin{tabular}{|c|c|c|c|c|c|c|c|c|}
\hline \multirow[b]{2}{*}{ Variants } & \multicolumn{2}{|c|}{ Ash } & \multicolumn{2}{|c|}{ Protein } & \multicolumn{2}{|c|}{ Acid number } & \multicolumn{2}{|c|}{ Oil number, $\%$} \\
\hline & $\%$ & $\begin{array}{l}\text { The ratio to } \\
\text { control }\end{array}$ & $\%$ & $\begin{array}{l}\text { The ratio to } \\
\text { control }\end{array}$ & mg KOH/g & $\begin{array}{l}\text { The ratio to } \\
\text { control }\end{array}$ & $\%$ & $\begin{array}{l}\text { The ratio to } \\
\text { control }\end{array}$ \\
\hline Control & 3.62 & - & 13.13 & - & 2.50 & - & 37.0 & - \\
\hline NP-Co -0.5 & 3.80 & +0.18 & 20.00 & +6.87 & 1.98 & -20.8 & 39.4 & +2.4 \\
\hline NP-Co -1.0 & 3.67 & +0.04 & 17.78 & +4.65 & 2.60 & +4.0 & 38.4 & +1.4 \\
\hline NP-Co -5.0 & 3.74 & +0.12 & 18.64 & +5.51 & 2.40 & -4.0 & 35.5 & -1.5 \\
\hline $\mathrm{HA}-0.5$ & 3.73 & +0.11 & 16.54 & +3.41 & 2.14 & -14.4 & 36.7 & +0.3 \\
\hline $\mathrm{HA}-1.0$ & 3.68 & +0.05 & 19.38 & +6.25 & 1.83 & -26.8 & 38.5 & +1.5 \\
\hline $\mathrm{HA}-5.0$ & 3.86 & +0.24 & 18.93 & +5.80 & 1.62 & -35.2 & 39.5 & +2.5 \\
\hline $\mathrm{NP}-\mathrm{Co}+\mathrm{HA}-0.5$ & 3.81 & +0.19 & 17.65 & +4.52 & 1.43 & -42.8 & 37.5 & +2.5 \\
\hline $\mathrm{NP}-\mathrm{Co}+\mathrm{HA}-1.0$ & 3.75 & +0.13 & 19.83 & +6.70 & 1.30 & -48.0 & 39.5 & +1.9 \\
\hline $\mathrm{NP}-\mathrm{Co}+\mathrm{HA}-5.0$ & 3.79 & +0.17 & 20.37 & +7.24 & 1.18 & -52.8 & 38.9 & +0.5 \\
\hline
\end{tabular}


plants. One can see the upper-range figures of this exponent in a case of seeds pre-plant treatment with the combination of cobalt and highly-dispersed humic acids. Biologically active nano-particles have also promoted protein increase in all experimental variants. The maximal protein increase in comparison with the control group has happened when we used the complex of humic acids and cobalt nano-particles. The positive gap with the control has been $7.24 \%$. On the average the protein quantity has been $5.2 \%$ higher than the control. The acid number characterizes the number of free fatty acids in oil. The high concentration of fatty acids leads to the decrease of storage time and quick spoiling of sunflower oil. The experiment seeds acid number in all the variants has been lower than that of the control. It proves the activation of the experiment plants lipidic exchange. The acid number in a case with humic acids has been lower than the control per 14.4\%-35.2\%. Cobalt nano-particles have promoted the decrease of the acid number on the average per $20 \%$. The combination of cobalt nano-particles and humic acids in an ultra-dispersed state has also contributed to the significant lowering of fatty acids number.

The oil content index is basic for the sunflower as it determines the purpose of these seeds. Oil content of all experiment seeds has exceeded the control. One can see the best results with $0.5 \mathrm{~g}$ cobalt nano-particles concentration $(+2.4 \%), \quad 5.0 \mathrm{~g}$ humic acids concentration $(+2.5 \%)$ and the combination of these biologically active substances with concentration $0.5 \mathrm{~g}$ per $2.5 \%$ against the control.

\section{Conclusions}

(1) Cobalt nano-particles, highly-dispersed humic acids and these substances complex have stimulated the sunflower seeds germination. The germinating power and lab coming-up have surpassed the control on the average per $7 \%$ and $15 \%$ correspondingly.

(2) The results of lab investigations have proved high biological activity of the used nano-particles and let determine the optimal concentrations of cobalt nano-particles, humic acids in nano-state and these substances complex. They are $0.5 \mathrm{~g}, 1.0 \mathrm{~g}$ and $5.0 \mathrm{~g}$ per hectare for planting the seeds correspondingly;

(3) Field germination, leaf-area duration, the height and the mass of the experiment sunflower plants in the vegetation period have surpassed the control data on the average per $15 \%$;

(4) Bio-chemical processes intensification when sunflower seeds' pre-plant treatment with cobalt nano-particles, humic acids in ultra-dispersed state and the combination of these substances has promoted the yield increase in all experiment variants. So oil seeds' yield in a case with $0.5 \mathrm{~g} / \mathrm{ha}$ cobalt nano-particles has been higher than that of the control per $24 \%$. The same index with $5.0 \mathrm{~g}$ /ha humic acids has been $19 \%$ and 0.5 $\mathrm{g} /$ ha combination of biologically active substances has been $31 \%$ higher.

\section{References}

[1] M.V. Kutskir, A.A. Nazarova, S.D. Polishchuk, Different cuprum fertilizers influence on physiologic, bio-chemical and productive indexes of spring wheat, Ecology and Ecosystem Exploitation: Selectas of International Symposium on Fundamental and Applied Problems of Science RAS 5 (2012) 135-152.

[2] M.V. Kutskir, A.A. Nazarova, S.D. Polishchuk, Physiologic grounding of different nano-particles use as sunflower plants growth stimulators, in: Materials of International Science and Practice Conference of Students and Candidaters for a Master's Degree "Chemical-Ecological Aspects of Research", conducted at International Forum of Students of Agricultural, Biological and Ecological Profiles "CHEMISTRY IN SCIENCE FAMILY”, Gorki, Belorussia, Gorki, BSAA. 2013, pp. 135-138.

[3] N.I. Golubeva, Y.N. Ivanycheva, A.A. Nazarova, S.D. Polishchuk, G.I. Churilov, Determining Nano-Materials Influence on Food and Fodder Plants According to Vital and Morpho-Physiologic Indexes, Guideline for Students, Aspirants and Researchers. Ryazan: RSATU Publishing House, 2013, p. 54.

[4] S.D. Polishchuk, A.A. Nazarova, M.V. Kutskir, Sunflower yield and bio-chemical composition when treated with cuprum nano-particles. RSATU Reporter 2 (18) (2013) 104-106.

[5] G.I. Churilov, A.A. Nazarova, S.D. Polishchuk, M.M. 

Stimulators of New Generation Growth

Sushilina, Ryazan Recommendations on Ultra-Dispersed Metal Powders (UDMP) Use in Agriculture, 2010, p. 51.

[6] G.I. Churilov, A.A. Nazarova, L.E. Ampleyeva, S.D. Polishchuk, O.V. Cherkasov, Biological Effect of Nano-Dimensioned Metals Influence on Different Groups of Plants, Monograph, Ryazan, 2010, p. 148.

[7] A.A. Nazarova, S.D. Polishchuk, I.A. Stepanova, G.I. Churilov, N.H. Chau, Biosafety of the application of biogenic nanometal powders in husbandry, in: The Main 4th International Workshop on Nanotechnology and Application, IWNA 2013, Vung Tau, Vietnam, 2013, pp. 291-295.

[8] G.I. Churilov, S.D. Polishchuk, A.A. Nazarova, Cuprum and cobalt nano-particles influence on bull-calves' growth and development, Journal of Materials Science and Engineering B 3 (2013) 379-385.

[9] G.I. Churilov, S.D. Polishchuk, N.H. Chau, Ecological and biological effects of nanocrystalline metals, in: 6th International Workshop on Advanced Materials Science and Nanotechnology and 6th Korea-Vietnam Joint Symposium on Photonics and Applications. Programme and Abstracts, Vietnam, 2012, p. 175.

[10] A.A. Nazarova, S.D. Polishchuk, I. A. Stepanova, G.I. Churilov, H.C. Nguyen, Q.B. Ngo, Biosafety of the application of biogenic nanometal powders in husbandry, J. C 5 1 (2014) 1-6.

[11] S.D. Polishchuk, A.A. Nazarova, T.V. Zheglova, Developing growth stimulators for agricultural plants on the basis of highly-dispersed humic acids, Catalogue: Nano-Technological Developments of Agrarian Universities, FSBSI "Rosinformagrotech", 2013, pp. 9-12.

[12] B.A. Dospehov, Field Experiment Technique, Agropromizdat, 1985, p. 351. 